Роман РОСЛЯк

\title{
«ТРЕСТ “УКРАЇНФІЛЬМ” ЛІКВІДУВАТИ...» Документи з історії формування сдиної централізованої системи управління радянською кіногалуззю
}

У статті аналізуються особливості уніфікаиії кінематографічного процесу і створення централізованої системи управління радянською кіногалуззю у другій половині 1930-х рр. До наукового обігу вводиться комплекс документів і матеріалів з означеного питання.

Ключові слова: трест «Українфільм», уніфікачія, иентралізація.

В статье анализируются особенности унификации кинематографического процесса и создание централизированной системь управления советской киноотраслью во второй половине 1930-х г2. В научный оборот вводится комплекс документов и материалов по данному вопросу.

Ключевые слова: трест «Украинфильм», унификаиия, централизаиия.

The article analyzes the features of the unification of the cinematographic process and the creation of a centralized control system for the Soviet film industry in the second half of the $1930 \mathrm{~s}$. To introduce complex scientific use of materials and documents definite issue.

Key words: trust «Ukrainfilm», unification, centralization.

Взаємодія держави й мистецтва - теми, що у науковців завжди викликають значний інтерес. Особливо це стосується «десятої музи», залежність якої від владних структур за часів СРСР була надзвичайно великою.

Те ж саме можна сказати і про українську кіногалузь, що впродовж незначного проміжку часу зазнала кардинальних трансформацій: від свого злету у 1920-х рр. до повного підпорядкування упродовж 1930-х і, як наслідок, втрати багатьох позицій. Відтак дослідження процесу трансформації української кіногалузі набуває неабиякого значення.

Певною мірою згадана проблематика була висвітлена в працях науковців радянської (Ю. Горячева [1]) та пострадянської доби (В. Михайлова [4], С. Марголіта [3], О. Кузюк [2] та ін.). Однак комплексне дослідження відсутнє ще й досі.

Окремі аспекти згаданої проблематики розглянуті автором і в попередніх трьох публікаціях. Це інкорпорація української кіногалузі до складу союзної (головним чином, що відбувалися в 1929 р.) [11]; особливості формування нормативно-правової бази вже об'єднаної радянської кінематографії у 1930 р. [10]; взаємини української та союзної кінематографій, передумови та особливості реформування радянської кінематографії, створення іï нової нормативно-правової бази на початку 1930 -х рр. [9]
Пропонована стаття є завершальною в циклі, що висвітлює процес підпорядкування української кіногалузі союзному центрові, починаючи 3 кінця 1920-х рр. і закінчуючи 1938-м роком. Мета публікації - проаналізувати особливості процесу, що відбувався у другій половині 1930-х рр., внаслідок чого були розформовані всі республіканські кіноорганізації і створена єдина централізована система управління радянською кіногалуззю. Традиційно метою публікації вважаємо введення до наукового обігу комплексу документів з означеної проблематики.

Актуальність пропонованої теми вбачаємо не лише в теоретичному аспекті, як то заповнення суттєвої прогалини в історії українського кіно (що сприятиме творенню цілісної концепції його розвитку), а й практичному - максимальному використанні минулого досвіду у сучасному кінопроцесі.

Наприкінці 1920-х рр. у Радянському Союзі почали посилюватися процеси централізації. Кінематографія не стала винятком. Намагаючись підпорядкувати та зробити максимально керованим «найважливіше 3 мистецтв», кремлівська партійна верхівка розпочала активний вплив на республіканські кіноорганізації, насамперед, на українську. Документи доводять, що вище республіканське керівництво певний час чинило актив- 
ний спротив спробам підпорядкувати національну кіногалузь інтересам центру. Однак зосередження одноосібної влади в одних руках (Й. Сталіна) та значне іiі посилення робили цей спротив малоефективним. Події початку 1930-го року, коли українська кінематографія втратила свою автономію підтверджують вищесказане.

Саме 1930 рік, коли відбулося формування нової нормативно-правової бази всієї радянської кінематографії, став поворотним і для українського кіно. Слід зауважити, що керівництво СРСР одразу вдалося до створення моделі доволі жорсткої вертикалі управління, що передбачала ліквідацію республіканських кіноорганізацій і безпосереднє підпорядкування всіх кінопідприємств та установ союзному центрові. Однак унаслідок певного спротиву (зокрема 3 боку вищого партійного керівництва УСРР) для вітчизняної кінематографії зробили виняток: у віданні українського кінотресту залишили виробництво фільмів (з цією метою йому були «підпорядковані» Київська та Одеська кінофабрики). Та загалом реформування негативно позначилося на розвиткові українського кіно, що втратило свою автономію. Відтепер вітчизняна кіногалузь ставала невід'ємною частиною радянської командно-адміністративної економіки.

Незадоволення, що наростало в республіках, та інші чинники змусили керівницво СРСР піти на певні поступки. У 1933 р. на різних рівнях було ухвалено нормативно-правову базу, що надавала більше прав республіканським кіноорганізаціям. Однак таке послаблення повноважень союзного центру було тимчасовим кроком. I, як показав подальший перебіг подій, у 1933 р. процес реформування кіногалузі не завершився. Пошук «оптимальної» моделі управління кінематографом у масштабах СРСР тривав ще впродовж кількох наступних років.

Чергова спроба «вдосконалення» механізму управління радянською кінематографією датується 17 січня 1936 року, коли з метою об'єднання всього керівництва розвитком мистецтв в СРСР була ухвалена постанова Центрального Виконавчого Комітету і Ради Народних Комісарів Союзу РСР «Про утворення Всесоюзного комітету в справах мистецтв при РНК Союзу РСР». На новостворений комітет було покладено керівництво всіма справами мистецтв і підпорядковано всі театри й інші видовищні мистецтва, кіноорганізації, музичні, художньо-живописні, скульптурні й інші заклади мистецтва, в тому числі й навчальні заклади, що готували для них фахівців [7]. До українського Управління в справах мистецтв при РНК УСРР (котре водночас являлося й органом Всесоюзного комітету у справах мистецтв) відійшло також і Управління фотокінопромисловості при РНК УСРР.

Та, як показав час, така централізація всіх мистецтв в одному відомстві не завжди дає бажані результати. Якщо ж урахувати, що кінематографія не $\epsilon$ «чистим мистецтвом», до того ж у кіновиробництві широко задіяні елементи промисловості (кіностудії, фабрики та заводи з виробництва фото- та кіноматеріалів, апаратури), то ставало зрозуміло, що кінематограф не вписувався в загальносоюзний центр з управління мистецтвом.

Пошуки іншої моделі управління кінематографом утім не припинялися. Ї̈̈ розробку було доручено С. Дукельському, який змінив розстріляного згодом Б. Шумяцького на посаді начальника Головного управління кінематографії.

23 березня 1938 року ухвалюється постанова Раднаркому СРСР «Про утворення Комітету в справах кінематографії при Раді Народних Комісарів Союзу РСР», що завершує процес повної централізації управління кінематографом.

Відповідно до цієї постанови на новостворену установу покладено «керівництво всіма справами кінематографії, в тому числі керівництво виробництвом кінокартин, кінофікацією і прокатом кінокартин по всьому Союзу РСР» [8]. До Комітету в справах кінематографії передавалися всі підприємства та організації кінематографії, що входили в систему Комітету в справах мистецтв при РНК СРСР по Головному управлінню кінематографії; кіностудії по РРФСР та інших союзних республіках; копіювальні фабрики і лабораторії масового копіювання кінофільмів. В Україні це були Київська і Одеська кіностудії художніх фільмів, Українська студія хронікально-документальних фільмів, Фабрика з виробництва плівки у м. Шостка, Одеський завод кіноапаратури, Київська копіювальна фабрика, Київський інститут кінематографії, Одеський кіномеханічний технікум, студія кінохроніки, що будувалася в Києві. Їх підпорядкували відповідним головним управлінням, створеним у складі Комітету. У республіках замість повноцінних органів з управління кінематографією (в Україні ці функції виконувало правління тресту «Українфільм») при радах народних комісарів утворювалися управління кінофікації як органи Комітету в справах кінематографії.

Принагідно зауважимо, що 23 березня 1938 р. голова союзного Раднаркому В. Молотов підписав інший, не менш «цікавий» документ — постанову 
«Про поліпшення організації виробництва кінокартин» [6]. Відтепер, крім усього іншого, кожен фільм запускався у виробництво лише за особливим наказом голови Комітету в справах кінематографії. Також без його попередньої санкції кіностудіям заборонялося вносити зміни до затверджених Комітетом режисерських сценаріїв.

Функції загальносоюзного центру було деталізовано в «Положенні про Комітет у справах кінематографії при Раді Народних Комісарів Союзу РСР», затвердженому 4 вересня 1938 року Раднаркомом СРСР. Наприклад, щодо виробництва фільмів, то Комітет не лише затверджував тематичні плани, але й для кожної кінокартини - літературний, режисерсько-монтажний сценарій i постановочний план. Більше того, кожна кінокартина запускалася у виробництво лише за особли- вим наказом голови Комітету! Аналогічна ситуація була і з випуском фільму на екран [5].

Таким чином, у 1938 році завершився процес повної централізації управління кінематографією, що був невід'ємною частиною формування в СРСР тоталітаризму. Тоталітаризму, який, за висловом В. Скуратівського, «зачепив і українське кіно. Фундаментально визначивши у притаманних йому стратегіях і (в найширшому значенні) „жанрах“ того часу його долю. I загальний, і той чи той „спеціальний“ його характер. Усю його естетичну та ідеологічну фактуру» $[12,77]$.

Пропонована публікація не претендує на вичерпність. На часі - розширення верхньої та нижньої хронологічних рамок, створення дослідження, що висвітлювало б дану проблематику в комплексі за весь радянський період.

\section{Постанова Центрального Виконавчого Комітету і Ради Народних Комісарів Союзу РСР «Про утворення Всесоюзного комітету в справах мистецтв при РНК Союзу РСР» 17 січня 1936 р., М. Москва}

У зв'язку з зростанням культурного рівня трудящих і необхідністю кращого задоволення запитів населення в галузі мистецтв і з метою об'єднання всього керівництва розвитком мистецтв у Союзі РСР - Центральний Виконавчий Комітет і Рада Народних Комісарів Союзу РСР постановляють:

1. Утворити при РНК Союзу РСР Всесоюзний комітет у справах мистецтв.

2. Покласти на Всесоюзний комітет у справах мистецтв керівництво всіма справами мистецтв, підпорядкувавши йому театри й інші видовищні підприємства, кіноорганізації, музичні, художньо-живописні, скульптурні й інші заклади мистецтва, в тому числі навчальні заклади, які готують працівників театру, кіно, музики і образотворчих мистецтв.

3. Зобов'язати народні комісаріати освіти союзних республік і інші органи, які мають у свойому віданні питання мистецтв, передати в місячний строк у відання Всесоюзного комітету в справах мистецтв зазначені в ст.2 заклади з установленими для цих закладів на 1936 рік матеріальними і фінансовими фондами.

4. Включити Головне управління кінофотопромисловості в систему Всесоюзного комітету в справах мистецтв.

5. Утворити при голові Всесоюзного комітету в справах мистецтв раду представників союзних і автономних республік.

6. Утворити при радах народних комісарів союзних республік (за винятком РСФРР і ЗСФРР), радах народних комісарів СРР Грузії, Вірменії, Азербайджана і автономних республік, при крайових і обласних виконавчих комітетах управління в справах мистецтв, які $\epsilon$ органами Всесоюзного комітету в справах мистецтв.

П р и м і т к а. Функції управління в справах мистецтв при Раді Народних Комісарів РСФРР здійснюються Всесоюзним комітетом в справах мистецтв.

7. Всесоюзний комітет у справах мистецтв при РНК Союзу РСР здійснює безпосереднє керівництво найвидатнішими художніми підприємствами й закладами всесоюзного значення за окремим списком, затверджуваним Радою Народних Комісарів Союзу РСР.

Керівництво підприємствами й закладами республіканського, крайового і обласного значення Всесоюзний комітет у справах мистецтв здійснює через управління в справах мистецтв при радах народних комісарів союзних і автономних республік, крайових і обласних виконавчих комітетах. 
8. Доручити голові Всесоюзного комітету в справах мистецтв у декадний строк подати на затвердження Ради Народних Комісарів Союзу РСР проект положення про комітет.

Голова ЦВК Союзу РСР М.Калінін

Голова РНК Союзу РСР В.Молотов

Секретар ЦВК Союзу РСР І.Акулов

Москва, Кремль. 17 січня 1936 р., 36/86

Збірник законів і розпоряджень Робітничо-селянського уряду Союзу Радянських Соиіалістичних Республік. - Відділ перший. — 1936. — №5 [13 лютого]. -Ст. 40.

\section{Постанова Центрального Виконавчого Комітету і Ради Народних Комісарів УСРР «Про утворення Українського управління в справах мистецтв при Раднаркомі УСРР»}

8 лютого 1936 р., м. Київ

У зв'язку з зростанням культурного рівня трудящих і необхідністю кращого задоволення попиту широких мас у галузі мистецтва, а також з метою об'єднання всього керівництва розвитком мистецтва на України, відповідно до постанови Центрального Виконавчого Комітету і Ради Народних Комісарів Союзу РСР від 17 січня 1936 року «Про утворення Всесоюзного комітету в справах мистецтв при РНК Союзу РСР» («33 СРСР», 1936 р., №5, ст.40) - Центральний Виконавчий Комітет і Рада Народних Комісарів УСРР п о с т а н о в ля ю т ь:

1. Утворити при Раді Народних Комісарів УСРР Українське управління в справах мистецтв.

2. Покласти на Управління в справах мистецтв керівництво всіма справами мистецтв на Україні з підпорядкуванням йому театрів та інших видовищних підприємств, кіноорганізацій, музичних, художньо-малярських, скульптурних і інших мистецьких установ, в тому числі учбових закладів, які готують кадри працівників театрів, кіно, музики і образотворчих мистецтв.

3. Зобов'язати Народний комісаріат освіти УСРР та інші органи, які мають в своєму віданні питання мистецтв, передати до 20 лютого у відання Управління в справах мистецтв усі згадані в п.2 установи з визначеними для цих установ на 1936 рік матеріальними й фінансовими фондами.

4. Включити Управління фотокінопромисловості при Раднаркомі УСРР в систему Управління в справах мистецтв.

5. Утворити при Раднаркомі АМСРР і обласних виконавчих комітетах управління в справах мистецтв, які безпосередньо підлягають Управлінню в справах мистецтв при Раднаркомі УСРР.

6. Управління в справах мистецтв при Раднаркомі УСРР безпосередньо здійснює керівництво найбільш видатними художніми підприємствами й установами республіканського значення за окремим списком, що його затверджує РНК УСРР.

Керівництво підприємствами й установами обласного значення Управління у справах мистецтв при РНК УСРР здійснює через Управління в справах мистецтв при РНК АМСРР і облвиконкомах.

7. Доручити начальнику Управління мистецтв при РНК УСРР в декадний строк подати на затвердження РНК УСРР проект положення про Українське управління мистецтв.

м. Київ, 8 лютого 1936 р.

Голова Центрального Виконавчого Комітету УСРР Г.Петровський

Голова Ради Народних Комісарів УСРР П.Любченко

Секретар Центрального Виконавчого Комітету УСРР Ю.Войцехівський

Збірник законів та розпоряджень Робітничо-селянського уряду України. - 1936. №6. - [10 лютого]. - C. 4-5. 


\section{Постанова Центрального Виконавчого Комітету УСРР \\ «Про призначення тов. Хвилі А. А. начальником Управління мистецтв при РНК УСРР»}

23 лютого 1936 р., м. Київ

Президія Центрального Виконавчого Комітету УСРР п о с т а н о в л я є:

Призначити тов. Хвилю Андрія Ананьєвича начальником Управління мистецтв при Раді Народних Комісарів УСРР, звільнивши його від обов'язків першого заступника народного комісара освіти УСРР.

м. Київ, 23 лютого 1936 р.

Голова Центрального Виконавчого Комітету УСРР Г.Петровський

Секретар Центрального Виконавчого Комітету УСРР Ю.Войцехівський

Збірник законів та розпоряджень Робітничо-селянського уряду Украйни. - 1936. №10. - [28 лютого]. - С. 8 .

\section{Постанова Ради Народних Комісарів Союзу РСР \\ «Про структуру Всесоюзного комітету в справах мистецтв при Раді Народних Комісарів Союзу РСР»}

5 січня 1937 р., м. Москва

На розвиток постанови ЦВК і РНК Союзу РСР від 17 січня 1936 року «Про утворення Всесоюзного комітету в справах мистецтв при РНК Союзу РСР» («33 СРСР», 1936 р., №5, ст.40) Рада Народних Комісарів Союзу РСР постановляє:

1. Встановити таку структуру Всесоюзного комітету в справах мистецтв:

a) Головне управління кінематографії;

б) Управління театрів;

в) Управління цирків;

г) Управління музичних установ;

д) Управління образотворчих мистецтв;

е) Відділ архітектури;

ж) Будівельне управління;

3) Плановий відділ;

и) Фінансовий відділ;

к) Секретаріат (з таємною частиною);

л) Адміністративно-господарський відділ;

м) Сектор обліку і розподілу керівних кадрів;

н) Інспекторська група;

о) Архів.

2. Встановити таку структуру Головного управління кінематографії Всесоюзного комітету в справах мистецтв:

а) Управління виробництва навчально-технічних фільмів;

б) Управління плівкової промисловості;

в) Управління кіномеханічної промисловості;

г) Управління виробництва художніх фільмів;

д) Управління кінофікації;

е) Планово-економічний відділ;

ж) Фінансовий відділ і Головна бухгалтерія;

3) Сектор капітального будівництва

и) Сектор підготовки кадрів;

к) Мобсектор;

л) Адміністративно-господарський сектор;

м) Сектор проглядів;

н) Секретаріат (з таємною частиною). 
3. Встановити, що при Всесоюзному комітеті в справах мистецтв перебуває Головне управління по контролю за репертуаром і видовищами, яке діє на підставі окремого положення, затверджуваного РНК Союзу РСР.

4. В безпосередньому підпорядкуванні Всесоюзного комітету в справах мистецтв перебувають:

а) Всесоюзна академія архітектури в Москві;

б) Академія художеств у Ленінграді;

в) Московська державна консерваторія;

г) Ленінградська державна консерваторія;

д) Всесоюзний трест фотографії і фотопромисловості («Союзфото»);

е) Об'єднане видавництво в питаннях театру, кіно, образотворчих мистецтв і архітектури («Искусство»);

ж) Музичне видавництво («Музгиз»).

5. Затвердити список театрів, госпрозрахункових організацій і установ загальносоюзного значення, безпосередньо підпорядкованих Всесоюзному комітетові в справах мистецтв по його управліннях (див. додаток № 1).

Затвердити список підприємств, що входять до складу тресту «Союзфото» (див. додаток №2 $2^{1}$ ).

Голова РНК Союзу РСР В.Молотов

Керівничий справ РНК Союзу РСР І.Мірошніков

Москва, Кремль. 5 січня 1937 р., №21

Збірник законів і розпоряджень Робітничо-селянського уряду Союзу Радянських Сойіалістичних Республік. - Відділ перший. — 1937. — №5 [16 січня]. - С. 23-24.

\section{3 додатку 1}

Додаток №1

до постанови РНК Союзу РСР від 5 січня 1937 р. №21

Список театрів, госпрозрахункових організацій і установ загальносоюзного значення, безпосередньо підпорядкованих Всесоюзному комітетові в справах мистецтв

І. По Головному управлінню кінематографії

1. Трест по виробництву хронікальних кінофільмів («Союзкинохроника»).

2. Всесоюзна контора по кіноекспорту і імпорту («Союзинторгкино»).

3. Кіностудія художніх фільмів у Москві («Мосфильм»).

4. Кіностудія художніх фільмів у Ленінграді («Ленфильм»).

5. Студія дитячих художніх фільмів у Москві («Союздетфильм»).

6. Студія мультиплікаційних фільмів у Москві («Союзмультфильм»).

7. Кіностудія художніх фільмів у Ялті.

8. Московська копіювальна фабрика.

9. Ленінградська копіювальна фабрика імені Першого травня.

10. Московська кіностудія науково-навчальних, оборонних i технічних фільмів («Мостехфильм»).

11. Ленінградська кіностудія науково-навчальних, оборонних і технічних фільмів («Лентехфильм»).

12. Новосибірська кіностудія науково-навчальних, оборонних і технічних фільмів.

13. Московська фабрика діапозитивів.

14. Фабрика по виробництву кіноплівки в м. Шостці.

15. Фабрика по виробництву кіноплівки в м. Переяславлі.

16. Фабрика по виробництву рентгеноплівки в Ленінграді.

17. Казанський новобудуваний кінохемічний комбінат у складі: фабрики кіноплівки, копіювальної фабрики, желатинового заводу і навчального комбінату.

18. Ленінградский завод кіноапаратури («Ленкинап»).

19. Одеський завод кіноапаратури («Кінап»).

\footnotetext{
${ }^{1}$ Не подається.
} 
20. Куйбишевський завод кіноапаратури.

21. Московський дослідний завод кіноапаратури.

22. Майстерня апаратури для плівкових фабрик у Москві.

23. Всесоюзна контора по постачанню і збуту кінопродукції («Киноснабсбыт»).

24. Всесоюзна контора по проектуванню підприємств кінематографії («Госкинопроект»).

25. Трест по промисловому будівництву («Кинопромстрой»).

26. Трест по будівництву Казанського кінохемічного комбінату.

27. Контора по управлінню кінотеатрами союзного значення («Союзкинотеатр») з підпорядкованими їй московськими кінотеатрами: «Ударник», «Детский», «Первый», «Колизей», «Метрополь», «Москва» і кінотеатром «Титан» у Ленінграді.

28. Всесоюзний державний інститут кінематографії (ВГИК).

29. Ленінградський інститут кіноінженерів (ЛИКИ).

30. Науково-дослідний інститут кіно і фотографії (НИКФИ).

31. Московський будинок кіно.

33. Ленінградський будинок кіно.

Збірник законів і розпоряджень Робітничо-селянського уряду Союзу Радянських Соџіалістичних Республік. - Відділ перший. — 1937. — №5 [16 січня]. - C. 24-25.

\section{Постанова Ради Народних Комісарів Союзу РСР «Про утворення Комітету в справах кінематографії при Раді Народних Комісарів Союзу РСР»}

Рада Народних Комісарів Союзу РСР постановляє:

1. У цілях поліпшення і об'єднання керівництва кінематографією, впорядкування справи кінофікації, виробництва і прокату кінофільмів - утворити при Раді Народних Комісарів Союзу РСР Комітет у справах кінематографії.

2. Покласти на Комітет у справах кінематографії при Раді Народних Комісарів Союзу РСР керівництво всіма справами кінематографії, в тому числі керівництво виробництвом кінокартин, кінофікацією і прокатом кінокартин по всьому Союзу РСР.

3. Передати в систему Комітету в справах кінематографії при Раді Народних Комісарів Союзу РСР:

а) всі підприємства і організації кінематографії, що входять в систему Комітету в справах мистецтв при РНК СРСР по Головному управлінню кінематографії;

б) кіностудії по РРФСР («Мосфільм», «Ленфільм», «Дитфільм» і ін.), а також кіностудії інших союзних республік: «Українфільм», Білдержкіно, Держкінпром Грузії, «Азерфільм», «Узбекфільм», «Туркменфільм», «Таджикфільм», копіювальні фабрики і лабораторії масового копіювання кінофільмів.

4. Утворити при радах народних комісарів союзних і автономних республік і при крайових і обласних виконавчих комітетах управління кінофікації як органи Комітету в справах кінематографії. Існуючі управління кінофікації при радах народних комісарів союзних республік влити в заново утворювані управління по кінофікації.

Управління кінофікації при Раднаркомі РРФСР ліквідувати, поклавши його функції на Комітет у справах кінематографії при РНК Союзу РСР.

Керівництво місцевими органами і трестами кінофікації республіканського, крайового і обласного підпорядкування Комітет у справах кінематографії при РНК Союзу РСР здійснює через управління кінофікації при радах народних комісарів союзних і автономних республік, крайових і обласних виконавчих комітетах.

5. Утворити при Комітеті у справах кінематографії Раду з участю представників союзних республік.

Покласти на Раду розгляд загальних тематичних планів виробництва кінокартин, кінофікації і прокату картин, ув'язування цих планів з національними особливостями республік. 
6. Організувати в системі Комітету в справах кінематографії при РНК Союзу РСР Всесоюзну контору по прокату кінофільмів («Союзкинопрокат») з наданням їй монопольного права прокату кінофільмів по Союзу РСР.

Трест по прокату кінокартин «Росснабфильм» ліквідувати з передаванням активу і пасиву, а також місцевих органів тресту «Союзкинопрокату».

Органи союзних республік по прокату кінокартин передати «Союзкинопрокату».

7. Встановити таку структуру Комітету в справах кінематографії при РНК Союзу РСР:

1) Головне управління по виробництву художніх фільмів.

2) Головне управління по виробництву наукових і навчально-технічних фільмів.

3) Головне управління по виробництву хронікально-документальних фільмів.

4) Головне управління кіноплівкової промисловості.

5) Головне управління кіномеханічної промисловості.

6) Головне управління кінофікації.

7) Головне управління масового копіювання і прокату кінофільмів.

8) Головне управління постачання.

9) Управління капітального будівництва.

10) Управління навчальними закладами.

11) Сценарний відділ.

12) Технічний відділ.

13) Планово-економічний відділ.

14) Фінансовий відділ.

15) Центральна бухгалтерія.

16) Сектор праці.

17) Сектор добору, обліку і розподілення кадрів.

18) Сектор переглядів.

19) Юридичний відділ з Арбітражем.

20) Контрольно-інспекторська група.

21) Управління справами.

22) Секретаріат (з секретною частиною).

Головні управління Комітету в справах кінематографії при РНК Союзу РСР керують підпорядкованими їм підприємствами на основі діючих законів про госпрозрахункові права підприємств, трестів і головних управлінь наркоматів.

8. Ліквідувати трест по виробництву хронікальних кінофільмів «Союзкинохроника», підпорядкувавши кіностудії тресту безпосередньо Комітетові в справах кінематографії по Головному управлінню виробництва хронікально-документальних фільмів.

9. Організувати в системі Комітету в справах кінематографії при Раднаркомі Союзу РСР, по Головному управлінню постачання, Всесоюзну контору по постачанню кіномережі «Союзкиноснаб».

10. Ліквідувати Всесоюзну контору по постачанню і збуту «Киноснабсбыт», передавши майно і справи контори Головному управлінню постачання Комітету в справах кінематографії.

11. Затвердити додаваний перелік виробничих і госпрозрахункових організацій і установ загальносоюзного значіння, безпосередньо підпорядкованих Комітету в справах кінематографії при РНК Союзу РСР і його головним управлінням.

12. Зобов'язати Комітет в справах мистецтв, ради народних комісарів союзних республік і інші органи передати в дводекадний строк Комітетові в справах кінематографії зазначені в статтях 3, 4 і 6 цієї постанови підприємства і організації з встановленими для них в 1938 році матеріальними і фінансовими фондами.

13. Доручити голові Комітету в справах кінематографії при РНК Союзу РСР в місячний строк внести в Раду Народних Комісарів Союзу РСР пропозиції у питаннях навчальної мережі по кінофікації.

14. Доручити голові Комітету в справах кінематографії при РНК Союзу РСР в дводекадний строк внести на затвердження Ради Народних Комісарів Союзу РСР проект положення про Комітет, штати і кошторис. 
Голова РНК Союзу РСР В.Молотов

Керуючий Справами РНК Союзу РСР М.Петрунічев

Москва, Кремль. 23 березня 1938 року, №382

Збірник постанов і розпоряджень Уряду Союзу Радянських Соџіалістичних Республік. - Відділ 1. - 1938. — №13 [11 квітня]. - С. 216-218.

\section{Додаток}

Затверджено

Радою Народних Комісарів Союзу РСР від 23 березня 1938 р.

Перелік підприємств, установ і організацій союзного значіння, що входять до складу Комітету у справах кінематографії при РНК Союзу РСР і його головних управлінь

\section{І. ПО ГОЛОВНОМУ УПРАВЛІННЮ ПО ВИРОБНИЦТВУ ХУДОЖНІХ ФІЛЬМІВ}

1. Московська кіностудія художніх фільмів «Мосфильм».

2. Ленінградська кіностудія художніх фільмів «Ленфильм».

3. Кіностудія дитячих художніх фільмів у Москві «Союздетфильм».

4. Кіностудія мультиплікаційних фільмів у Москві «Союзмультфильм».

5. Київська кіностудія художніх фільмів.

6. Одеська кіностудія художніх фільмів.

7. Кіностудія художніх фільмів «Советская Белорусь» у м. Ленінграді.

8. Тбіліська кіностудія художніх фільмів.

9. Бакінська кіностудія художніх фільмів.

10. Среванська кіностудія художніх фільмів.

11. Ташкентська кіностудія художніх фільмів.

12. Ашхабадська кіностудія художніх фільмів.

13. Сталінабадська кіностудія художніх фільмів.

14. Ленінградський будинок кіно.

15. Московський будинок кіно.

\section{II. ПО ГОЛОВНОМУ УПРАВЛІННЮ ПО ВИРОБНИЦТВУ НАУКОВИХ I НАВЧАЛЬНО-ТЕХНІЧНИХ ФІЛЬМІВ}

1. Московська кіностудія наукових і навчально-технічних фільмів «Мостехфильм».

2. Ленінградська кіностудія наукових і навчально-технічних фільмів «Лентехфильм».

3. Новосибірська кіностудія наукових і навчально-технічних фільмів «Сибтехфильм».

4. Московська фабрика діапозитивів «Диафильм».

\section{III. ПО ГОЛОВНОМУ УПРАВЛІННЮ ПО ВИРОБНИЦТВУ ХРОНІКАЛЬНО- ДОКУМЕНТАЛЬНИХ ФІЛЬМІВ}

1. Московська студія хронікально-документальних фільмів.

2. Українська -//-

3. Ленінградська -//-

4. Ростовська -//-

5. Алма-Атинська -//-

6. Воронізька -//-

7. Горьковська $-/ /-$

8. Іркутська $-/ /-$

9. Казанська $-/ /-$

10. Куйбишевська -//-

11. Новосибірська -//-

12. Саратовська -//- 

13. Свердловська $-/ /-$
14. Ташкентська $-/ /-$
15. Уфімська $-/ /-$
16. Хабаровська $-/ /-$
17. Чебоксарська $-/ /-$
18. Енгельська $-/ /-$
19. Мінська $-/ /-$

\section{IV. ПО ГОЛОВНОМУ УПРАВЛІННЮ КІНОПЛІВКОВОЇ ПРОМИСЛОВОСТІ}

1. Фабрика по виробництву плівки в м. Шостці.

2. Фабрика по виробництву плівки в м. Переяславлі.

3. Фабрика по виробництву плівки в м. Ленінграді.

4. Фабрика по виробництву плівки в м. Казані.

V. ПО ГОЛОВНОМУ УПРАВЛІННЮ КІНОМЕХАНІЧНОЇ ПРОМИСЛОВОСТІ

1. Ленінградський завод кіноапаратури.

2. Одеський завод кіноапаратури.

3. Куйбишевський завод кіноапаратури.

4. Московський дослідний завод кіноапаратури.

\section{VI. ПО ГОЛОВНОМУ УПРАВЛІННЮ МАСОВОГО КОПІЮВАННЯ І ПРОКАТУ КІНОФІЛЬМІВ}

1. Ленінградська копіювальна фабрика.

2. Московська копіювальна фабрика.

3. Київська копіювальна фабрика.

4. Тбіліська копіювальна фабрика.

5. Мінська копіювальна фабрика.

6. Всесоюзна контора «Союзкинопрокат».

7. Контора по управлінню кінотеатрами союзного значіння «Союзкинотеатр» 3 підпорядкованими їй кінотеатрами: «Ударник», «Метрополь», «Детский», «Первый», «Колизей», «Москва» і ленінградський кінотеатр «Титан».

\section{VII. ПО ГОЛОВНОМУ УПРАВЛІННЮ ПОСТАЧАННЯ}

1. Всесоюзна контора по постачанню кіномережі «Союзкиноснаб» і її місцеві відділи.

\section{VIII. ПО УПРАВЛІННЮ НАВЧАЛЬНИМИ ЗАКЛАДАМИ}

1. Всесоюзний державний інститут кінематографії (ВГИК).

2. Ленінградський інститут кіноінженерів (ЛИКИ).

3. Київський інститут кінематографії.

4. Акторска кіношкола при «Мосфільмі».

5. Акторська кіношкола при «Ленфільмі».

6. Казанський технікум кіноплівки.

7. Одеський кіномеханічний технікум.

\section{ІХ. ПІДПРИЄМСТВА І ОРГАНІЗАЦІЇ, ПІДПОРЯДКОВАНІ БЕЗПОСЕРЕДНЬО КОМІТЕТОВІ В СПРАВАХ КІНЕМАТОГРАФІЇ}

1. Казанський кінохемічний комбінат по виробництву кіноплівки, желатину і ін., що будується.

2. Трест по будівництву Казанського кінохемічного комбінату «Казкинохимстрой». 
3. Всесоюзна контора по кіноекспорту й імпорту «Союзинторгкино».

4. Науково-дослідний інститут кінофото - НИКФИ, м. Москва.

5. Науково-дослідний інститут кінобудівництва - НИИКС, м. Москва.

6. Всесоюзне фільмосховище, що будується.

7. Студія кінохроніки, що будується в м. Москві.

8. Студія кінохроніки, що будується в м. Києві.

Збірник постанов і розпоряджень Уряду Союзу Радянських Сойіалістичних Республік. - Відділ перший. - 1938. — №13 [11 квітня]. — С. 218-220.

\section{Постанова Ради Народних Комісарів Союзу РСР «Про поліпшення організації виробництва кінокартин»}

23 березня 1938 р., м. Москва

Рада Народних Комісарів Союзу РСР встановлює, що в справі організації виробництва художніх кінокартин мають місце крупні дефекти, що приводять до систематичного невиконання програми випуску кінокартин, безгосподарності, розбазарюванню державних коштів, виробництву великої кількості браку, здорожанню і затягуванню виробництва кінокартин.

Одним з головних дефектів у роботі кіностудій є неправильна система планування по випадкових заявках на сценарії і антидержавна практика планування так званих умовних одиниць (тема без назви і сценарія), що утворює можливість одержання державних коштів в порядку фінансування неіснуючого виробництва кінокартин і розбазарювання цих коштів. Тим самим систематично зривається виробництво картин і виконання директив керівних органів в частині тематичного напрямку плану.

Відсутність чітко розробленого технологічного процесу виробництва, відсутність розмежування періоду підготовки до виробництва від самого процесу виробництва фільмів, а також пускання фільмів у виробництво без затвердження режисерсько-монтажних сценаріїв, без постановочних планів і кошторисів, приводили до безгосподарської витрати державних коштів (непотрібні здіймання, витрати на виїзди здіймальних експедицій, що дорого коштують, оплата перестоїв акторів, пошивка костюмів і т.ін.). Постановочні плани і кошториси на виробництво картин складалися, як правило, вже в процесі виробництва або при закінченні виробництва.

Існуюча система фінансування виробництва картин за рахунок процентних відрахувань від прокатних надходжень за раніше випущені фільми давала можливість кіностудіям довгий час покривати величезні перевитрати і збитки від перестоїв і від виробництва браку навіть в кіностудіях, що не випускали ні однієї картини за рік (Вірменкіно, частково Білдержкіно).

Істотною хибою роботи кіностудій $є$ неправильне завантаження основних творчих кадрів - режисерів - роботою по складанню сценаріїв. Це утворює неприпустимо довгі перерви у використанні режисерів по прямому призначенню, викликає великі перестої і знижує щорічний випуск фільмів.

Великою хибою $є$ нерівномірний запуск кінофільмів у виробництво, що приводить до перестоїв великих колективів працівників кіностудій в першому півріччі і штурмовщини в другому; улаштування великих по масштабу непотрібних декорацій, повторна робота цехів з-за відсутності переносних, розібраних (фундусних) декорацій для використання по декількох картинах. Все це знижує ефективність використання кіностудій, викликає надмірну трату матеріальних коштів, перестої і перерви в здійманні кінокартин.

3 метою поліпшення організації виробництва кінокартин і використання технічної бази кіностудій Рада Народних Комісарів Союзу РСР постановляє:

1. Осудити антидержавну практику проведення здіймань кінокартин без затвердження Комітетом в справах кінематографії при РНК Союзу РСР режисерсько-монтажних сценаріїв і кошторисів. 
2. Утворити в складі Комітету в справах кінематографії і в кіностудіях сценарні відділи 3 покладанням на них завдання забезпечення плану виробництва картин сценаріями $\mathrm{i}$ утворення резерву сценаріїв для нормального і рівномірного завантаження творчих кадрів і технічної бази кінематографії.

Основну увагу сценарних відділів направити на широке втягування кадрів письменників, драматургів і молодих починаючих авторів і організацію консультації і допомоги їм в роботі. Звільнити робітників сценарних відділів від функцій контролю і нагляду за виробництвом кінокартин.

3. Обмежити функції режисерів по сценаріях головним чином розробкою режисерських сценаріїв.

Кіностудіям приступити до звільнювання режисерських кадрів від невластивих їм функцій сценаристів з переключанням їх на роботу за фахом.

4. Обмежити період підготовки виробництва кінокартин такими заходами: а) розробкою режисерсько-монтажного сценарія; б) складанням постановочного плану і кошторису; в) розробкою ескізів декорацій і костюмів і г) добором акторів. Заборонити проведення яких би то не було матеріальних затрат в період підготовки виробництва картин, крім як на зазначені вище заходи.

5. Скасувати існуючий порядок вирахування і фінансування заходів підготовчого періоду в умовних процентах і одиницях по виробництву картин. Запропонувати Комітетові в справах кінематографії сплачувати вартість робіт підготовчого періоду по спеціальних, наперед затверджених їм кошторисах, з наступним перерахуванням цих витрат на вартість відповідної картини.

6. Дозволити пускання у виробництво кінокартин лише при наявності затверджених режисерсько-монтажних сценаріїв, постановочних планів, кошторисів, ескізів, декорацій і костюмів і спроб акторів. Відповідно з цим запропонувати голові Комітету дозволяти пускання кожної картини у виробництво особливим наказом.

Категорично заборонити кіностудіям проведення робіт і затрат, не передбачених постановочними кошторисами.

7. Заборонити кіностудіям внесення змін до затверджених Комітетом у справах кінематографії режисерських сценаріїв без попередньої санкції голови Комітету.

8. Комітету в справах кінематографії в двомісячних строк розробити єдину форму постановочного плану і кошторису, усунувши громіздкість існуючих форм, що завантажує непотрібними деталями і розрахунками апарати кіностудій. Також переглянути розцінки i систему розрахунку цехів, майстерень і складів кіностудій за послуги здіймальним групам, усунувши антидержавну практику встановлення підвищених розцінок для перестрахування від збитків, не передбачених кошторисами.

9. Для більш раціонального використання площ павільйонів кіностудій провести такі заходи:

а) ущільнити робочий день в кіностудіях з завантаженням павільйонів у три зміни, використовуючи третю зміну для влаштування декорацій;

б) зменшити об'єм декорацій, широко використовуючи метод домалювань, а також скоротити строки будування декорацій, забезпечивши у всіх студіях систематичне освоєння i використання переносних, розбірних (фундусних) декорацій;

в) винести частину павільйонних здіймань на натурні площадки поблизу студій;

г) винести за межі студій в інші відповідні приміщення процес тонування і оркестрові репетиції;

д) щоб уникнути перестоїв павільйонів - змінити систему притягання акторів для здіймання, в особливості з інших міст або зайнятих в здійманнях по декількох картинах.

10. Скасувати існуючу практику фінансування виробництва кіностудій за рахунок прокатних відрахувань по експлуатації раніше випущених кінокартин. Голові Комітету в справах кінематографії в декадний строк розробити і внести на затвердження в Раду Народних Комісарів Союзу РСР правила по фінансуванню виробництва кінокартин, забезпечивши залежність фінансового стану кіностудій від результатів виконання плану виробництва кінокартин. 
11. Передбачити утворення спеціального фонду для преміювання творчих працівників i інженерно-технічного персоналу і робітників-стахановців кіностудій за рахунок відрахувань від суми зниження вартості кінокартин по даній кіностудії.

Голова РНК Союзу РСР В.Молотов

Керуючий справами РНК Союзу РСР М.Петрунічев

Москва, Кремль. 23 березня 1938 року, №384

Збірник постанов і розпоряджень Уряду Союзу Радянських Сойіалістичних Республік. — Відділ перший. — 1938. — №13 [11 квітня]. — С. 220-222.

\section{Постанова Ради народних комісарів УРСР «Про створення Управління кінофікації при Раді Народних Комісарів УРСР, Раді Народних Комісарів Молдавської АРСР і обласних виконавчих комітетах»}

16 квітня 1938 р., м. Київ

89. Об образовании Управления кинофикации при Совете Народных Комиссаров УССР, Совете Народных Комиссаров Молдавской АССР и областных исполнительных комитетах

В соответствии с постановлением Совета Народных Комиссаров Союза ССР от 23 марта 1938 года №382 «Об образовании Комитета по делам кинематографии при Совете Народных Комиссаров Союза ССР» («Собр[ание] пост[ановлений] СССР», 1938 г., №13, ст.81) и в целях упорядочения дела кинофикации в УССР Совет Народных Комиссаров УССР постановляет:

1. Образовать при Совете Народных Комиссаров УССР Управление кинофикации.

2. Возложить на Управление кинофикации при Совете Народных Комиссаров УССР следующие основные задачи:

a) руководство всем делом кинофикации УССР;

б) развитие и расширение киносети в городе и на селе;

в) качественный подъем работы киносети, в частности дальнейшее озвучение ее;

г) лучшая организация культурного обслуживания кинозрителей города и села;

д) лучшая организация эксплоатация киносети.

3. Установить следующую структуру Управления кинофикации при Совете Народных Комиссаров УССР:

а) отдел оперативно-эксплоатационный;

б) отдел технический;

в) отдел капитального строительства;

г) отдел подготовки, учета и распределения кадров;

д) отдел планово-экономический;

е) отдел финансовый и бухгалтерия;

ж) отдел административно-хозяйственный.

4. Совету Народных Комиссаров Молдавской АССР и областным исполнительным комитетам в двухдекадный срок образовать Управление кинофикации при Совете Народных Комиссаров Молдавской АССР и областные управления кинофикации при областных исполнительных комитетах.

5. Начальнику Управления кинофикации при Совете Народных Комиссаров УССР в месячный срок представить на утверждение Совета Народных Комиссаров УССР проекты положения об управлениях кинофикации при Совете Народных Комиссаров УССР, Совете Народных Комиссаров Молдавской АССР и об областных управлениях кинофикации, а также проект нового типового устава областного кинотреста.

6. Заместителю начальника Управления по делам искусств при Совете Народных Комиссаров УССР в декадный срок передать Комитету по делам кинематографии при Совете Народных Комиссаров Союза ССР все предусмотренные в постановлении Совета Народных Комиссаров Союза ССР от 23 марта 1938 года №382 предприятия и организации «Украинфильма» со всеми установленными для них на 1938 год материальными и финансовыми фондами. 
Передачу оформить в установленном законом порядке.

7. Трест «Украинфильм» ликвидировать, а все дела, имущество и ценности его передать в Управление кинофикации при Совете Народных Комиссаров УССР.

8. Поручить начальнику Управления кинофикации при Совете Народных Комиссаров УССР, по соглашению с Комитетом кинематографии при Совете Народных Комиссаров Союза ССР, разработать следующие вопросы:

a) об образовании, на базе аппарата бывшего хозрасчетного управления снабсбыта «Украинфильма», хозрасчетной снабженческой конторы при Управлении кинофикации УССР — «Укркиноснаб»;

б) об образовании в г. Киеве городского кинотреста.

Свои предложения представить на утверждение Совета Народных Комиссаров УССР.

9. Народному комиссариату финансов УССР в течение декады установить штаты и смету Управления кинофикации при Совете Народных Комиссаров УССР и обеспечить Управление кинофикации при Совете Народных Комиссаров УССР соответствующими ассигнованиями за счет сметы «Украинфильма» на 1938 год.

г. Киев, 16 апреля 1938 года

Председатель Совета Народных Комиссаров УССР Д.Коротченко

Собрание законов и распоряжений Рабоче-крестьянского правительства Украинской Советской Социалистической Республики. — 1938. — №23 [29 апреля]. — С. 8.

\section{Постанова Ради Народних Комісарів Союзу РСР «Про затвердження Положення про Комітет в справах кінематографії при Раді Народних Комісарів Союзу РСР»}

Рада Народних Комісарів Союзу РСР постановляє:

1. Затвердити Положення про Комітет в справах кінематографії при Раді Народних Комісарів Союзу РСР.

2. Внести такі зміни і доповнення до переліку підприємств, установ і організацій союзного значення, що входять до складу Комітету в справах кінематографії, затвердженого РНК Союзу РСР 23 березня 1938 року («Збір[ник] пост[анов] СРСР», 1938 р., №13, ст.81):

a) Казанський кінохемічний комбінат по виробництву кіноплівки, желатина i iн., що будується, підпорядкувати Головному управлінню кіноплівкової промисловості;

б) Трест по будівництву Казанського кінохемічного комбіната («Казкинохимстрой») підпорядкувати Управлінню капітального будівництва;

в) утворити у віданні Управління капітального будівництва Всесоюзний трест по проектуванню підприємств кінопромисловості і кінотеатрів («Союзкинопроект»);

г) доповнити зазначений вище перелік такими установами і підприємствами:

По Управлінню навчальними закладами

1. Ленінградський кінотехнікум;

2. Ростовский на Дону кінотехнікум;

3. Воронізький кінотехнікум;

4. Вітебський кінотехнікум;

5. Київський кінотехнікум;

6. Акторська кіношкола при Тбіліській кіностудії художніх фільмів.

По Головному управлінню кіномеханічної промисловості

1. Ленінградська кіномеханічна майстерня;

2. Саратовська кіномеханічна майстерня;

4. Ярославська кіномеханічна майстерня.

Підприємства і організаџії, підпорядковані безпосередньо Комітетові в справах кінематографіï

1. Кіностудія художніх фільмів, що будується в м. Мінську;

2. Кіностудія художніх фільмів, що будується в м. Баку. 
Голова РНК Союзу РСР В.Молотов

Керуючий справами РНК Союзу РСР М.Петрунічев

Москва, Кремль. 4 вересня 1938 року, №965

Збірник постанов і розпоряджень Уряду Союзу Радянських Соџіалістичних Республік. - Відділ 1. - 1938. — №40 [15 вересня]. - C.522.

\section{Положення про Комітет у справах кінематографії при Раді Народних Комісарів Союзу РСР}

4 вересня 1938 р., м. Москва

Затверджено

Радою Народних Комісарів Союзу РСР

4 вересня $1938 \mathrm{p}$.

I.

1. Комітет в справах кінематографії при Раді Народних Комісарів Союзу РСР у відповідності з постановою РНК Союзу РСР від 23 березня 1938 року «Про утворення Комітету в справах кінематографії при РНК Союзу РСР» («Збір[ник] пост[анов] СРСР», 1938 р., №13, ст.81) керує всіма справами кінематографії, а також керує фотопромисловістю.

2. Комітет в справах кінематографії при РНК Союзу РСР здійснює керівництво:

а) виробництвом художніх фільмів;

б) виробництвом наукових і навчально-технічних фільмів;

в) виробництвом хронікально-документальних фільмів;

г) виробництвом кіноплівки;

д) виробництвом кіноапаратури;

е) масовим друком копій фільмів;

ж) кінофікацією;

3) прокатом фільмів;

и) фотопромисловістю;

к) капітальним будівництвом кіно- і фотопромислових і постачальницько-збутових підприємств;

л) науково-дослідницькою роботою по кінематографії і фотопромисловості;

м) підготовкою кадрів для кінематографії і фотопромисловості;

н) видавництвом по питанням кінематографії і фотографії.

3. Комітет в справах кінематографії при Раді Народних Комісарів Союзу РСР:

a) розробляє і вносить на розгляд Уряду СРСР питання розвитку радянської кінематографії і фотопромисловості;

б) складає і подає на затвердження Уряду СРСР виробничі і фінансові плани (квартальні, річні, п'ятирічні), а також плани капітального будівництва по кінематографії і фотопромисловості, і керує виконанням затверджених планів; затверджує у встановленому порядку проекти і кошториси будівництва;

в) затверджує тематичні плани виробництва кінокартин;

г) затверджує для кожної кінокартини літературний і режисерсько-монтажний сценарій і постановочний план; дозволяє особливим наказом пуск кожної картини до виробництва; дозволяє випуск кожної кінокартини на екран;

д) забезпечує широке залучення радянських письменників до літературно-творчої роботи в кінематографії і організовує конкурси на літературні сценарії;

е) розробляє питання технічної політики і здійснює технічне керівництво кінофотопромисловістю; організовує науково-дослідницьку роботу в галузі кінематографії і фотопромисловості; розглядає винаходи і технічні вдосконалення в цій галузі; керує їх впровадженням, видає авторські свідоцтва і патенти на винаходи; затверджує технічні умови, зразки і стандарти на продукцію кінофотопромисловості;

ж) керує розгортання кіномережи; затверджує технічні норми по експлуатації кіномережи і здійснює контроль за ії технічним станом; 
3) затверджує правила проката кінокартин; в межах, встановлених Раднаркомом Союзу РСР, регулює тарифи на прокат кінокартин і ціни на квитки в кінотеатри і кіноустановки трестованої і нетрестованої кіномережи;

и) затверджує репертуарні плани і здійснює контроль за кінорепертуаром і демонструванням фільмів у кінотеатрах і на кіноустановках всіх відомств і організацій;

к) керує організацією праці, нормуванням праці і заробітної плати, а також керує розвитком соціалістичного змагання і стахановського руху на підприємствах, підвідомчих Комітетові;

л) веде підготовку художньо-творчих, технічних і господарських кадрів для кінематографії і фотопромисловості через підвідомчі Комітетові вищі навчальні заклади, технікуми і курси; організовує облік і розподілення кадрів;

м) організовує технічне і матеріальне постачання підвідомчих Комітетові підприємств; керує збутом і затверджує ціни на продукцію цих підприємств;

н) організовує кіновиставки, олімпіади, огляди і кінофестивалі для показу кращих досягнень кінематографії;

о) організовує експорт і імпорт кінокартин і фотовидань і устатковання для кінематографії і фотосправи і показ радянських кінокартин за кордоном;

п) організовує збереження негативів кінокартин.

4. Комітет в справах кінематографії при Раді Народних Комісарів Союзу РСР складається з голови Комітету, його заступників і членів Комітету, затверджуваних Радою Народних Комісарів Союзу РСР.

5. Голова Комітету керує всією роботою Комітету; видає, в межах своєї компетенції, накази і інструкції на підставі і у виконання діючих законів, а також постанов і розпоряджень Ради Народних Комісарів Союзу РСР, і перевіряє їх виконання; призначає і звільняє працівників центрального апарата Комітету, а також керівних працівників підвідомчих Комітетові трестів, контор і підприємств.

6. Комітет має регулярні засідання і розглядає, перш за все, питання практичного керівництва, перевірки виконання, добору кадрів, звіти працівників місцевих органів, істотні накази і інструкції.

Рішення Комітету проводяться як накази голови Комітету.

В разі розбіжностей між головою і членами Комітету голова Комітету проводить в життя своє рішення, повідомляючи про виниклі розбіжності в Раду Народних Комісарів Союзу РСР, а члени Комітету, в свою чергу, можуть апелювати в Раду Народних Комісарів Союзу РСР.

II.

7. Комітет в справах кінематографії при РНК Союзу РСР має такі головні управління:

а) Головне управління по виробництву художніх фільмів, яке управляє студіями по виробництву художніх фільмів і керує будинками кіно;

б) Головне управління по виробництву наукових і навчально-технічних фільмів, яке управляє студіями по виробництву наукових і навчально-технічних фільмів і фабрикою по виробництву діапозитивів;

в) Головне управління по виробництву хронікально-документальних фільмів, яке управляє студіями по виробництву хронікально-документальних фільмів;

г) Головне управління кіноплівкової промисловості, яке управляє фабриками по виробництву кіноплівки, рентгеноплівки і фотоплівки;

д) Головне управління кіномеханічної промисловості, яке управляє заводами по виробництву кіноапаратури і запасних до неї частин;

е) Головне управління фотографічної промисловості, яке управляє підприємствами фотопромисловості;

ж) Головне управління масового друку і прокату фільмів, яке управляє кінокопіювальними фабриками і керує Всесоюзною конторою по прокату фільмів («Союзкинопрокат») i конторою «Союзкинотеатр»;

3) Головне управління кінофікації, через яке Комітет здійснює керівництво і контроль за роботою управлінь і трестів кінофікації (республіканських, крайових, обласних). Голов- 
не управління кінофікації розробляє плани розвитку і експлуатації кіномережи, як підвідомчої Комітетові, так і тої, що знаходиться у віданні інших народних комісаріатів, відомств і організацій Союзу РСР і союзних республік;

и) Головне управління постачання, яке розподіляє фонди матеріалів і устатковання, постачає неплановими матеріалами підприємства і будівництва Комітету, організовує постачання кіномережи апаратурою, устаткованням, запасними частинами і кіноприладдями через підпорядковану йому Всесоюзну контору по постачанню кіномережи («Союзкиноснаб»).

8. Головні управління і Управління капітального будівництва Комітету в справах кінематографії при РНК Союзу РСР керують підвідомчими їм підприємствами і організаціями на основі діючих законів про госпрозрахункові права підприємств, трестів і головних управлінь наркоматів.

9. На чолі головного управління стоїть начальник управління. Начальник головного управління здійснює господарське і технічне керівництво підпорядкованими головному управлінню підприємствами і організаціями.

10. В головних управліннях по кінопромисловості, фотопромисловості і кінофікації організуються такі відділи і сектора:

виробничо-розпорядливий відділ;

технічний відділ — в головних управліннях кіномеханічної, кіноплівкової, фотографічної промисловості і кінофікації;

сектор капітального будівництва;

відділ постачання і збуту;

група праці і зарплати;

плановий сектор;

фінансовий сектор;

бухгалтерія і інші відділи і сектора.

11. Виробничо-розпорядливі відділи головних управлінь здійснюють повсякденний контроль, оперативний вплив і допомогу в роботі підпорядкованих головному управлінню підприємств, для чого встановлюються посади диспетчерів, прикріплюваних до підприємств.

Виробничо-розпорядливі відділи (постановочно-розпорядливі відділи) головних управлінь по виробництву художніх, наукових і навчально-технічних і хронікально-документальних фільмів, зокрема, розглядають режисерсько-монтажні сценарії і постановочні плани, подавувані на затвердження голови Комітету, переглядають зняті матеріали, дають висновки по закінчених виробництвом фільмах; стежать за відповідністю фільма, що знаходиться у виробництві, затвердженому режисерсько-монтажному сценарію; розробляють і стежать за здійсненням в кіностудіях заходів по поліпшенню організації постановочної роботи, кращому використанню устатковання і здіймальних площ павільйонів кіностудій, скороченню строків побудови декорації, максимальному використанню фундуса і впровадженню при здійманні фільмів методів комбінованого здіймання і т.д.; розробляють заходи і стежать за станом техніки безпеки і охорони праці в кіностудіях.

Для керівництва і контролю по технічних питаннях в складі виробничо-розпорядливих відділів головних управлінь по виробництву фільмів організовуються технічні групи.

12. Технічні відділи головних управлінь кіномеханічної, кіноплівкової і фотографічної промисловості розробляють питання технічної політики даної галузі; розробляють технологічні схеми виробництва, правила технічної експлуатації, технічні вимірники і стежать за їх виконанням; розробляють заходи по поліпшенню використання устатковання і впровадженню нових типів устатковання, економії дефіцитних матеріалів, впровадженню їх замінювачів, а також правила ремонту устатковання, і стежать за їх виконанням; розробляють питання розвитку кіноапаратобудування і освоєння нових зразків апаратури і сортів кіно- i фотоплівки, фотоплатівок і фотопаперу; розбирають причини аварій і розробляють заходи по їх попередженню і ліквідації; розробляють заходи по техніці безпеки на підприємствах.

Технічний відділ Головного управління кінофікації розробляє питання технічної реконструкції кіномережи, а також розробляє правила технічної експлуатації для кіномережи і стежить за їх виконанням. 
13. Сектор капітального будівництва Головного управління розробляє плани капітального будівництва; розробляє типові проекти будівництва; здійснює повсякденний контроль за виконанням планів будівництва як по строках, так і по якісних показниках, а також контроль за забезпеченням будівництва проектами і кошторисами; подає оперативну допомогу будівництвам.

\section{III.}

14. При голові Комітету в справах кінематографії $€$ контрольно-інспекторська група, на яку покладається перевірка виконання головними управліннями, управліннями, відділами, секторами Комітету, трестами, всіма господарськими організаціями і підприємствами Комітету постанов Партії і Уряду по питаннях кінематографії і фотопромисловості, наказів і інструкцій Комітету в справах кінематографії.

15. Комітет в справах кінематографії має такі відділи, управління і інші підрозділи апарату:

a) Сценарний відділ, на який покладається забезпечення плану виробництва кінокартин сценаріями; розгляд літературних сценаріїв і подавання їх на затвердження голови Комітету; створення резерву сценаріїв для нормального і рівномірного завантаження творчих кадрів і технічної бази кінематографії; широке притягання письменників, драматургів, композиторів і молодих починаючих авторів до створення сценаріїв, організація для них консультації і допомоги в їх роботі;

б) Технічний відділ, на який покладається розробка питань технічної політики в галузі виробництва кінокартин; розробка правил технологічного процеса і технічної експлуатації устатковання кіностудій; розробка комплексних технічних питань кінематографії (питання кольорового кіно, денного кіно, вузькоплівкового кіно і т.д.); розробка і контроль за проведенням заходів по довгочасному збереженню плівки і фільмів; вивчання новіших досягнень закордонної кінотехніки; давання висновків по технічних питаннях, подаваних головними управліннями на розв'язання голови Комітету; давання висновків по технологічній частині технічних проектів, подаваних на затвердження голови Комітету; розглядання i подавання на затвердження голови Комітету тематичних планів науково-дослідницьких інститутів Комітету і науково-дослідницьких робіт, здійснюваних на підприємствах; нагляд за виконанням планів науково-дослідницьких робіт інститутів і підприємств; розглядання важливіших винаходів в галузі кінематографії і фотографії і подавання пропозицій по їх впровадженню на затвердження голови Комітету; облік і контроль за впровадженням винаходів і технічних вдосконалень на підприємствах; видача авторських свідоцтв і патентів на винаходи;

в) Управління по контролю за кінорепертуаром, на яке покладається здійснення державного контролю над кінорепертуаром і демонструванням фільмів у кінотеатрах і на кіноустановках всіх відомств і організацій;

г) Планово-економічний відділ, на який покладається розробка поточних і перспективних планів кінематографії, подавання їх голові Комітету, нагляд і контроль за їх виконанням; проведення систематичного обліку і оперативна інформація про роботу кінематографії;

д) Управління капітального будівництва, на яке покладається розробка зведених планів капітального будівництва і капіталовкладень в системі Комітету і подавання їх голові Комітету; розглядання подаваних головними управліннями на затвердження голови Комітету проектних завдань, проектів і кошторисів; керівництво новобудівлями, проектними і будівельними організаціями; контроль за виконанням планів капітального будівництва в усій системі Комітету як по строках, так і по якісних показниках;

е) Сектор праці, на який покладається розробка і регулювання питань праці і заробітної плати в системі Комітету; нагляд за правильною організацією праці, що забезпечує підвищення продуктивності і розвиток стахановського руху; нагляд за станом техніки безпеки на підприємствах;

ж) Сектор добору, обліку і розподілення кадрів, на який покладається підготовка для голови Комітету пропозицій по призначенню працівників і розподіленню закінчуючих навчальні заклади; облік господарників, художньо-творчих працівників, інженерів і техніків; 
3) Управління навчальними закладами, на яке покладається організація справи підготовки кадрів в системі Комітету, керівництво навчальними закладами, безпосередньо підпорядкованими Комітетові; розробка навчальних планів, методичне керівництво навчальними закладами, підпорядкованими місцевим управлінням кінофікації; інструктування і інспектування роботи цих навчальних закладів;

и) Фінансовий відділ, на який покладається складання зведених фінансових планів, подавання їх на затвердження голови Комітету і контроль за їх виконанням; нагляд за фінансовою роботою головних управлінь Комітету, підприємств і організацій, підпорядкованих Комітетові; здійснення фінансування підвідомчих Комітетові установ і підприємств;

к) Центральна бухгалтерія, на яку покладається здійснення бухгалтерського обліку; інструктування і нагляд за роботою органів Комітету по бухгалтерському обліку і звітності; розглядання звітів і балансів господарських організацій Комітету; проведення документальних ревізій;

л) Сектор переглядів, на який покладається організація і проведення, у відповідності 3 вказівками голови Комітету, перегляду кінокартин;

м) Юридичний відділ з Арбітражем;

н) Мобілізаційний сектор;

о) Управління справами;

п) Секретаріат (з секретною частиною).

16. У веденні Комітету в справах кінематографії є Видавництво періодичної і книжкової літератури і плакатно-рекламної продукції по питаннях кінематографії і фотографії («Госкиноиздат»).

IV.

17. Для зв'язку з місцями і обміну досвідом при голові Комітету є Рада з участю представників союзних республік. Рада скликається один раз в два місяці і розглядає важливіші питання кінематографії і фотографії, зокрема, загальні і тематичні плани виробництва кінокартин, кінофікації і прокату картин, ув'язку цих планів з національними особливостями республік.

Склад Ради затверджується Радою Народних Комісарів Союзу РСР по представленню голови Комітету в справах кінематографії при РНК Союзу РСР.

18. Голова Комітету в справах кінематографії при РНК Союзу РСР у цілях використання досвіду господарських, художньо-творчих і інженерно-технічних працівників і робітників-стахановців кінематографії і фотопромисловості і для розгортання критики і самокритики скликає щомісяця актив Комітету. Відповідно, в головних управліннях Комітету, в трестах і на підприємствах керівники скликають активи, на яких заслуховують і обговорюють доповіді про важливіші рішення Партії і Уряду і керівні вказівки Комітету.

$\mathrm{V}$.

19. При радах народних комісарів союзних і автономних республік, крайових і обласних виконавчих комітетах утворюються управління кінофікації, які є органами Комітету в справах кінематографії і діють на основі положень, затверджуваних радами народних комісарів союзних республік за згодою з Комітетом в справах кінематографії при РНК Союзу РСР.

20. Начальники управлінь кінофікації при радах народних комісарів союзних республік призначаються радами народних комісарів союзних республік за згодою з головою Комітету в справах кінематографії.

Начальники управлінь кінофікації при радах народних комісарів автономних республік і при крайових і обласних виконавчих комітетах призначаються радами народних комісарів автономних республік, крайовими і обласними виконавчими комітетами за згодою 3 начальниками управлінь кінофікації при радах народних комісарів союзних республік, а по автономних республіках, краях і областях РРФСР - за згодою з головою Комітету в справах кінематографії.

Голова Комітету в справах кінематографії при РНК Союзу РСР

С. Дукельський

Збірник постанов і розпоряджень Уряду Союзу Радянських Соціалістичних Республік. - Відділ 1. - 1938. — №40 [15 вересня]. — С. 523-529. 


\section{Постанова Ради Народних Комісарів УРСР \\ «Про організацію контори «Укркінопостач» при Управлінні кінофікації при Раді Народних Комісарів УРСР»}

5 липня 1939 р., м. Київ

На розвиток постанови Ради Народних Комісарів УРСР від 16 квітня 1938 р. «Про утворення Управління кінофікації при Раді Народних Комісарів УРСР» («33 УРСР», 1938 р., №23, ст.89) Рада Народних Комісарів УРСР постановляє:

1. Дозволити Управлінню кінофікації при Раді Народних Комісарів УРСР для постачання матеріалів та встаткованні всій трестованій та нетрестованій кіносітці організувати госпрозрахункову контору «Укркінопостач».

2. Повернені «Союзкінопостачем» Управлінню кінофікації при Раді Народних Комісарів УРСР оборотні кошти, які раніш одержані для української філії «Союзкінопостачу», передати новоутворюваній госпрозрахунковій конторі «Укркінопостач» як її оборотні кошти.

3. Доручити начальникові Управління кінофікації при Раді Народних Комісарів УРСР, в погодженні з народними комісаріатами фінансів та юстиції УРСР, затвердити положення про «Укркінопостач».

4. Народному комісаріатові фінансів УРСР разом з Управлінням кінофікації при Раді Народних Комісарів УРСР протягом декади встановити штати та кошторис «Укркінопостачу» на 1939 рік.

5. Дозволити обласним виконавчим (організаційним) комітетам та Раді Народних Комісарів АРСР 22 в в погодженні з Управлінням кінофікації при Раді Народних Комісарів УРСР, перевести на госпрозрахунок відділи постачання та збуту обласних кінотрестів.

м. Київ, 5 липня 1939 року, №709

Голова Ради Народних Комісарів УРСР Д. Коротченко

Керуючий справами Ради Народних Комісарів УРСР О.Шинкарьов

Збірник постанов і розпоряджень Уряду Украӥнської Радянської Соџіалістичної Республіки. - Відділ 1. - 1939. - №23 [19 липня]. - С. 5.

\section{Постанова Ради Народних Комісарів УРСР «Про встановлення при Раді Народних Комісарів УРСР посади Уповноваженого Комітету в справах кінематографії по прокату кінофільмів»}

13 грудня 1940 р., м. Київ

Рада Народних Комісарів УРСР постановляє:

1. Відповідно до розпорядження Ради Народних Комісарів Союзу РСР від 16 листопада 1940 р. №040 встановити при Раді Народних Комісарів УРСР посаду Уповноваженого Комітету в справах кінематографії по прокату кінофільмів.

2. Доручити Уповноваженому Комітету в справах кінематографії по прокату кінофільмів, в погодженні з Народним комісаріатом фінансів УРСР та Комітетом у справах кінематографії при Раді Народних Комісарів Союзу РСР, опрацювати і подати Раді Народних Комісарів УРСР проект структури і штатів Управління Уповноваженого Комітету в справах кінематографії по прокату кінофільмів та кошторис.

м. Київ, 13 грудня 1940 р., №1658

Заст[упник] Голови Ради Народних Комісарів УРСР В. Старченко

Заст[упник] керуючого справами Ради Народних Комісарів УРСР С.Суліма

Збірник постанов і розпоряджень Уряду Украӥнської Радянської Соціалістичної Республіки. - Відділ 1. - 1941. - №2 [16 січня]. - С. 18.

2 Так у тексті.

\section{Джерела та література}

1. Горячев Ю.И. История строительства советской кинематографии (1926-1932 гг.) / Ю. И. Горячев. — М., 1981. — 69 с.

2. Кузюк О.Управління українським кінематографом у 1930-х роках [Електронний ресурс]. — Режим до- ступу: http: // http://www.nbuv.gov.ua/portal/Soc_Gum/ Gileya/2011_48/Gileya48/I19_doc.pdf

3. Марголит Е. Дело восьми. $\overline{\mathrm{K}}$ истории одного документа / Евгений Марголит [Електронний ресурс]. — Режим доступу: http://seance.ru/n/43-44/perekrestok/zakaz/delovosmi-k-istorii-odnogo-dokumenta/ 
4. Михайлов В.Сталинская модель управления кинематографом / Владимир Михайлов // Кино: политика и люди (30-е годы) : К 100-летию мирового кино. - М. : Материк, 1995. - С. 9-25.

5. Положение о Комитете по делам кинематографии при Совете Народных Комиссаров Союза ССР от 4 сентября 1938 года // Бюллетень Комитета по делам кинематографии при СНК Союза ССР. - 1938. - №1/2. - С. 15.

6. Про поліпшення організації виробництва кінокартин: Постанова Ради Народних Комісарів Союзу РСР від 23 березня 1938 р. // Збірник постанов і розпоряджень Уряду Союзу Радянських Соціалістичних Республік. - Відділ перший. — 1938. — №13 [11 квітня]. — С. 220-222.

7. Про утворення Всесоюзного комітету в справах мистецтв при РНК Союзу РСР: Постанова Центрального Виконавчого Комітету і Ради Народних Комісарів Союзу РСР від 17 січня 1936 року // Збірник законів і розпоряджень Робітничо-селянського уряду Союзу Радянських Соціалістичних Республік. - Відділ перший. — 1936. — №5 [13 лютого]. - Арт. 40.

8. Про утворення Комітету в справах кінематографії при Раді Народних комісарів Союзу РСР: Постанова Ради Народних Комісарів Союзу РСР від 23 березня 1938 року // Збірник законів і розпоряджень уряду Союзу Радянських Соціалістичних Республік. - 1938. — №13 [11 квітня]. - Арт. 81.

9. Росляк Р. «„Союзкіно“ утворює таку організаційну структуру, яка в розумінні бюрократизації керівництва йде навіть далі, ніж це було до цього часу»: Документи й матеріали 3 історії функціонування української кінематографії під владою союзного центру (початок 1930 -х рр.) / Роман Росляк // Науковий вісник Київського національного університету театру, кіно і телебачення імені І.К. Карпенка-Карого. — К., 2017. — Вип. 20. — С. 187-205.

10. Росляк Р. «Проти повного скасування республіканських організацій ми рішуче заперечуємо»: Документи й матеріали з історії формування нової нормативно-правової бази радянської кінематографії (1930р.) / Роман Росляк // Науковий вісник Київського національного університету театру, кіно і телебачення імені І. К. Карпенка-Карого. К., 2016. - Вип. 19. - С. 206-219.

11. Росляк Р. «Українська кінематографія ні в якому разі не може погодитися на утворення всесоюзного кіносиндикату...»: Документи й матеріали з історії втрати вітчизняною кіногалуззю автономного статусу / Роман Росляк // Науковий вісник Київського національного університету театру, кіно і телебачення імені І. К. Карпенка-Карого. К., 2016. - Вип. 18. - С. 150-161.

12. Скуратівський В.Українське тоталітарне кіно / Вадим Скуратівський // Нариси з історії кіномистецтва України / Редкол. : В. Сидоренко (голова) та ін. ; Інститут проблем сучасного мистецтва Академії мистецтв України. - К. : Інтертехнологія, 2006. - С. 77-116.

\section{References}

1. Goryachev, Yu. I. Istoriya stroitelstva sovetskoy kinematografii (1926-1932 gg.) / Yu. I. Goryachev. - M., 1981. - $69 \mathrm{~s}$.
2. Kuzyuk, O. UpravlInnya ukraYinskim kInematografom u 1930-h rokah [Elektronniy resurs]. - Rezhim dostupu: http:// http://www.nbuv.gov.ua/portal/Soc_Gum/Gileya/2011_48/ Gileya48/I19_doc.pdf

3. Margolit, E. Delo vosmi. K istorii odnogo dokumenta / Evgeniy Margolit [Elektronniy resurs]. - Retrieved from: http://seance.ru/n/43-44/perekrestok/zakaz/delo-vosmi-kistorii-odnogo-dokumenta/

4. Mihaylov, V. Stalinskaya model upravleniya kinematografom/ Vladimir Mihaylov // Kino: politika i lyudi (30-e godyi) : K 100-letiyu mirovogo kino. - M. : Materik, 1995. S. 9-25.

5. Polozhenie o Komitete po delam kinematografii pri Sovete Narodnyih Komissarov Soyuza SSR ot 4 sentyabrya 1938 goda // Byulleten Komiteta po delam kinematografii pri SNK Soyuza SSR. - 1938. - \#1/2. - S. 15.

6. Pro polipshennia orhanizatsii vyrobnytstva kinokartyn: Postanova Rady Narodnykh Komisariv Soiuzu RSR vid 23 bereznia 1938 r. // Zbirnyk postanov i rozporiadzhen Uriadu Soiuzu Radianskykh Sotsialistychnykh Respublik. - Viddil pershyi. - 1938. — №13 [11 kvitnia]. - S. 220-222.

7. Pro utvorennia Vsesoiuznoho komitetu v spravakh mystetstv pry RNK Soiuzu RSR: Postanova Tsentralnoho Vykonavchoho Komitetu i Rady Narodnykh Komisariv Soiuzu RSR vid 17 sichnia 1936 roku // Zbirnyk zakoniv i rozporiadzhen Robitnycho-selianskoho uriadu Soiuzu Radianskykh Sotsialistychnykh Respublik. - Viddil pershyi. - 1936. — №5 [13 liutoho]. - Art. 40.

8. Pro utvorennia Komitetu $\mathrm{v}$ spravakh kinematohrafii pry Radi Narodnykh komisariv Soiuzu RSR: Postanova Rady Narodnykh Komisariv Soiuzu RSR vid 23 bereznia 1938 roku//Zbirnyk zakoniv i rozporiadzhen uriadu Soiuzu Radianskykh Sotsialistychnykh Respublik. - 1938. — №13 [11 kvitnia]. - Art. 81.

9. Rosliak, R. ",Soiuzkino“ utvoriuie taku orhanizatsiinu strukturu, yaka $\mathrm{v}$ rozuminni biurokratyzatsii kerivnytstva yde navit dali, nizh tse bulo do tsoho chasu»: Dokumenty y materialy z istorii funktsionuvannia ukrainskoi kinematohrafii pid vladoiu soiuznoho tsentru (pochatok 1930 -kh rr.) / Roman Rosliak // Naukovyi visnyk Kyivskoho natsionalnoho universytetu teatru, kino i telebachennia imeni I. K. KarpenkaKaroho. - K., 2017. - Vyp. 20. - S. 187-205.

10. Rosliak, R. «Proty povnoho skasuvannia respublikanskykh orhanizatsii my rishuche zaperechuiemo»: Dokumenty y materialy $\mathrm{z}$ istorii formuvannia novoi normatyvno-pravovoi bazy radianskoi kinematohrafii (1930 r.) / Roman Rosliak // Naukovyi visnyk Kyivskoho natsionalnoho universytetu teatru, kino i telebachennia imeni I. K. Karpenka-Karoho. K., 2016. - Vyp. 19. - S. 206-219.

11. Rosliak, R. «Ukrainska kinematohrafiia ni v yakomu razi ne mozhe pohodytysia na utvorennia vsesoiuznoho kinosyndykatu...»: Dokumenty y materialy z istorii vtraty vitchyznianoiu kinohaluzziu avtonomnoho statusu / Roman Rosliak // Naukovyi visnyk Kyivskoho natsionalnoho universytetu teatru, kino i telebachennia imeni I. K. KarpenkaKaroho. - K., 2016. - Vyp. 18. - S. 150-161.

12. Skurativskyi, V. Ukrainske totalitarne kino / Vadym Skurativskyi // Narysy z istorii kinomystetstva Ukrainy / Redkol. : V.Sydorenko (holova) ta in. ; Instytut problem suchasnoho mystetstva Akademii mystetstv Ukrainy. - K. : Intertekhnolohiia, 2006. - S. 77-116. 